\title{
Разработка технологии сухого концентрата напитка на основе модифицированного пектина с добавлением дикоросов Дальнего Востока
}

\section{Андрей Подкорытов*, Ирина Кадникова, Елена Подкорытова, Валерий Ковалев}

Дальневосточный федеральный университет, г. Владивосток, Россия Национальный научный центр морской биологии им. А.В. Жирмунского ДВО РАН, г. Владивосток, Россия

\section{Информация о статье Поступила в редакцию: 07.07.2019 \\ Принята \\ к опубликованию:}

21.11.2019

УДК 663.86.054.1

JEL 014

\section{Ключевые слова:}

пектин, филлоспадикс, элеутерококк, шиповник, боярышник, адаптогены, флавоноиды, функциональный продукт, безалкогольный напиток, сухой концентрат

\section{Keywords:}

pectin, phyllospadix, eleutherococcus, rosehip, hawthorn, adaptogens, flavonoids, functional product, soft beverage, dry concentrate

\begin{abstract}
Аннотация
Разработана технология и рецептура сухого концентрата напитка, содержащего функииональные ингредиенты: гидролизованный пектин из Phyllospadix iwatensis, элеутерозиды, флавоноиды, аскорбиновую кислоту. Определены дозы всех ингредиентов с учетом норм суточного потребления. Исследован процесс гранулирования композищии пектина $и$ сахарозы с добавлением экстрактов элеутерококка, ииповника и боярышника. Содержание пектина, элеутерозидов и аскорбиновой кислоты в однократной дозировке напитка (10 г) составляет $100 \%$ от адекватного суточного уровня потребления, а флавоноидов - 20,5\%. Проведена органолептическая оченка напитка и определены его основные физико-химические показатели. Исследованы показатели безопасности сухого концентрата напитка.
\end{abstract}

Development of technology of a Dry Concentrate Beverage Based on modified pectin with the addition of Far East Wild Plants

Andrey Podkorytov, Irina Kadnikova, Elena Podkorytova, Valeri Kovalev

Abstract

The technology of obtaining a dry concentrate of a functional beverage based on hydrolyzed pectin from sea grass Phyllospadix iwatensis with the addition of extracts of eleutherococcus, rosehip and hawthorn is presented. In order to classify the beverage as a functional, we used a composition containing $20 \%$ pectin. Quantitative determination of eleutheroside B and ascorbic acid was performed by HPLC with spectrophotometric detection at $270 \mathrm{~nm}$ and $243 \mathrm{~nm}$, respectively. The quantitative content of the total flavonoids (in terms of rutin) was determined by the spectrophotometric method at a wavelength of $406 \mathrm{~nm}$. To improve the organoleptic characteristics, citric acid, stevioside and elderberry extract were added to the beverage. The formulation of the beverage was developed in accordance with the

\footnotetext{
* Автор для связи: podkorytov_a_g@mail.ru

DOI http://dx.doi.org/10.24866/2311-2271/2019-3/165-177
} 
requirements of the State Standard of Russia number 28188-2014 and the norms of daily consumption. Consumer properties were assessed according to the current regulatory documents of the Russian Federation $(R D R F)$ and the countries of the Eurasian Economic Union. The organoleptic evaluation of the drink was carried out in accordance with ISO 11035: 1994 and State Standard of Russia number 6687.5-86, the main physical and chemical indicators (titrated acidity, humidity, mass fraction of dry substances and minerals) were determined. The resulting beverage has a sweetish taste and a pleasant berry aroma with a pronounced rosehip smell. According to the terms of storage, the drink was in accordance with State Standard of Russia number 6687.6-88. The main standard indices of the safety of the drink according to TR CU 021/2011 - the content of heavy metals, microbiological indices. The quality and safety indices of the developed product corresponded to the requirements of the Russian Federation and the EAEC.

\section{Введение}

Напитки являются самым потребляемым продуктом питания человека, а также наиболее технологически выгодной основой для создания новых видов функционального питания. В последнее время в производстве функциональных продуктов все чаще используют полисахариды. Особую значимость имеют продукты на основе морских полисахаридов, которые не только регулируют структуру продукта, но и модифицируют его биологическую ценность.

Пектины морского происхождения в наибольшей степени отвечают эти требованиям. Их используют в пищевой промышленности в качестве загустителей и гелеобразователей при производстве джемов, фруктовых консервов, желе и безалкогольных напитков [1].

Пектины из морских трав относятся к уникальным природным низкоэтерифицированным пектинам и обладают большим разнообразием фармакологических эффектов. Важным отличием низкоэтерифицированных пектинов от пектинов наземного происхождения является их способность сорбировать и прочно связывать в своей молекулярной структуре ионы тяжелых металлов [2$6]$.

В ареале российского побережья Приморья запасы морских трав составляют порядка 100 тысяч тонн, основная часть которых представлена Phyllospadix iwatensis. Высокая сорбционная активность филлоспадикса позволяет рекомендовать его к использованию в качестве энтеросорбента в пищевой и фармацевтической промышленности [7-9].

В настоящее время в производстве функциональных напитков особую значимость приобретает использование отечественного сырья из лекарственных растений Дальнего Востока, применяемых для профилактики и лечения различных заболеваний. Экстракты из лекарственного растительного сырья обладают направленным биологическим действием и являются перспективным сырьем в разработке функциональных безалкогольных напитков. Растительные экстракты повышают тонус организма и обладают антиоксидантным действием, повышают адаптивные возможности нервной системы и устойчивость организма к воздействию неблагоприятных факторов окружающей среды, а также служат оптимальными источниками хорошо усвояемых микроэлементов $[10,11]$.

В качестве источников флавоноидов, обладающих антиоксидантным действием, были выбраны плоды боярышника (Crataegi fructus) и шиповника (Rosae fructus), в качестве источника адаптогенов - элеутерококк колючий (Eleutherococcus senticosus). 
Целью данной работы является разработка технологии сухого концентрата напитка на основе гидролизованного пектина из Phyllospadix iwatensis с добавлением элеутерококка колючего, плодов боярышника и шиповника.

\section{Материалы и методы исследования}

В работе были использован гидролизованный пектин из морской травы Phyllospadix iwatensis, имеющий следующие характеристики: степень деметок-

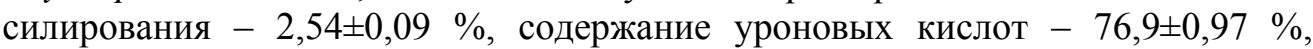
среднечисленная молекулярная масса - 52,1 кДа, средневесовая молекулярная масса - 112,21 кДа.

В качестве объектов исследований использовали: экстракт корневищ и корней элеутерококка колючего жидкий (ОАО «Дальхимфарм», Россия) по ВФС 42-1281; плоды боярышника (ЗАО «Ст.-Медифарм», Россия) по ГОСТ 3852; плоды шиповника (ООО «Фарм-Продукт», Россия) по ГОСТ 1994; сахар белый по ГОСТ 33222-2015; кислота аскорбиновая по ФС 42-2668; кислота лимонная по ГОСТ 908; подсластитель «стевиозид» (ООО «Витачай», Россия); экстракт бузины импортный по гигиеническому заключению. В качестве вспомогательных материалов при изготовлении напитка на основе пектина использовали: спирт этиловый питьевой 95\%-ный по ГОСТ Р 51723-2001, воду питьевую по СанПиН 2.1.4.1074.

Жидкие экстракты плодов шиповника и боярышника были получены метом перколяции согласно Государственной фармакопее.

Количественное определение элеутерозида В и аскорбиновой кислоты проводилось методом ВЭЖХ на хроматографической системе LC-20 AD Prominence в комплекте со спектрофотометрическим детектором (SPD-20AV Prominence UV/VIS Detector, Shimadzu), с хроматографической колонкой (Shim-pack VP-ODS, 4,6 х 250 мм) с предколонкой (Shim-pack GVP-ODS 10L x 4,6 мм). Данные по хроматографии были обработаны с помощью программы Shimadzu LabSolutions.

Для определения элеутерозида В в качестве элюента А использовали раствор концентрированной фосфорной кислоты в воде с объемным соотношением $(0,5: 99,5)$, элюент В - ацетонитрил. Условия хроматографического определения: подвижная фаза: ацетонитрил — раствор фосфорной кислоты $(15: 85)$ в процентах по объему; скорость подачи элюента: 1,0 мл/мин; детектирование при длине волны 270 нм; температура колонки $40^{\circ} \mathrm{C}$; объем пробы 20 мкл.

Массовую концентрацию аскорбиновой кислоты проводили в ультрафиолетовой области спектра при длине волны 243 нм. Условия хроматографического определения были следующими: подвижная фаза: 0,1 М раствор дигидрофосфата калия $\mathrm{pH} 2,5$; скорость потока подачи элюента 0,7 мл/мин; температура колонки $35^{\circ} \mathrm{C}$; объем пробы 20 мкл.

Количественное содержание суммы флавоноидов (в пересчете на рутин) экстракта шиповника и боярышника определяли на спектрофотометре Shimadzu UV-1800 при длине волны 406 нм.

Количество лимонной кислоты, стевиозида, а также жидких экстрактов шиповника, боярышника и бузины определялось путем оценки органолептических показателей готового напитка - цвета, вкуса и запаха.

Органолептические показатели напитка оценивали с помощью профильного метода по ISO 11035:1994, ГОСТ 6687.5-86. Массовую долю сухих веществ в концентрате определяли по ГОСТ 6687.2-90, минеральные вещества - 
по ГОСТ 15113.8-77, влажность концентрата — по ГОСТ Р 52610-2006, титруемую кислотность - потенциометрически по ГОСТ 6687.4-86.

Исследования безопасности сухого концентрата напитка были проведены в соответствии с ТР ТС 021/2011. Определяли содержание тяжелых металлов (свинец, мышьяк, кадмий, ртуть), а также уровень микробиологической безопасности (КМАФАнМ, БГКП, патогенные микроорганизмы, дрожжи и плесени, E. coli).

\section{Результаты исследования и их обсуждение}

На основании данных по растворимости пектина, полученных нами ранее [12] в качестве оптимальной была выбрана композиция, содержащая 20 \% пектина из филлоспадикса и $80 \%$ сахарозы.

На первом этапе при составлении рецептуры сухого концентрата напитка, как функционального продукта, рассчитывали количество функциональных ингредиентов - пектина, элеутерозидов и аскорбиновой кислоты с учетом рекомендаций с ориентацией на их суточный адекватный уровень потребления [13].

Учитывая 20\% содержание пектина в смеси, а также его адекватный уровень потребления 2,0 г/сут., было решено в качестве основы для рецептуры сухого концентрата напитка взять однократную дозировку в 10,0 г.

Для расчета необходимого количества жидкого экстракта элеутерококка в нем определялось содержание элеутерозида В. По результатам экспериментов были получены хроматограммы экстракта элеутерококка жидкого (рис. 1 А) и готового напитка (рис. 1 Б).
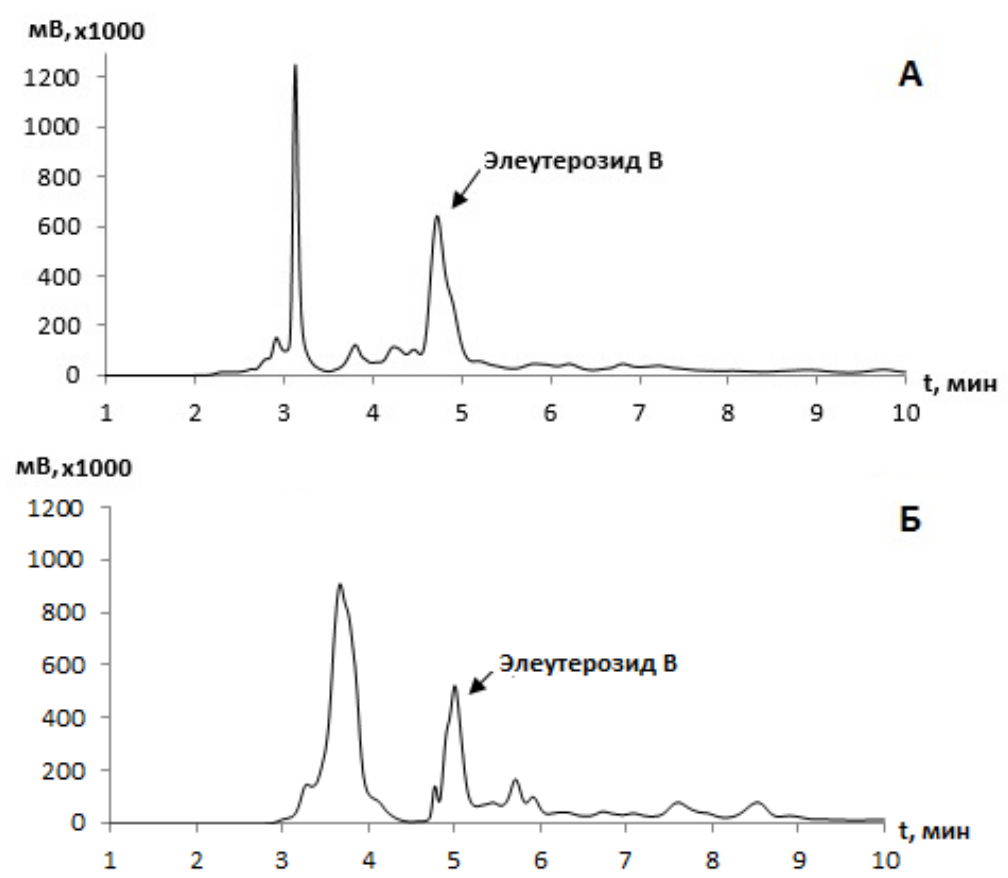

Puc. 1. Хроматограмма экстракта элеутерококка жидкого (разведение 1:5) готового напитка на основе пектина с добавлением элеутерококка (A), боярышника и шиповника (Б) 
В ходе проведенных исследований установлено содержание элеутерозида В в экстракте элеутерококка жидком $-0,178 \%$ и в готовом напитке $-0,01 \%$. Установленное содержание элеутерозида В в исходном экстракте элеутерококка составило 1,78 мг/мл. Соответственно, 1,0 мг элеутерозида В (суточный адекватный уровень потребления) содержится в 0,562 мл жидкого экстракта.

Добавление в рецептуру экстрактов шиповника и боярышника, лимонной кислоты, стевиозида и экстракта бузины основывалось на органолептической оценке напитка - цвета, вкуса и запаха.

Определено содержание аскорбиновой кислоты в жидких экстрактах плодов шиповника и боярышника. По результатам экспериментов были получены хроматограммы экстракта плодов шиповника (рис. 2 А), экстракта плодов боярышника (рис. 2 Б).
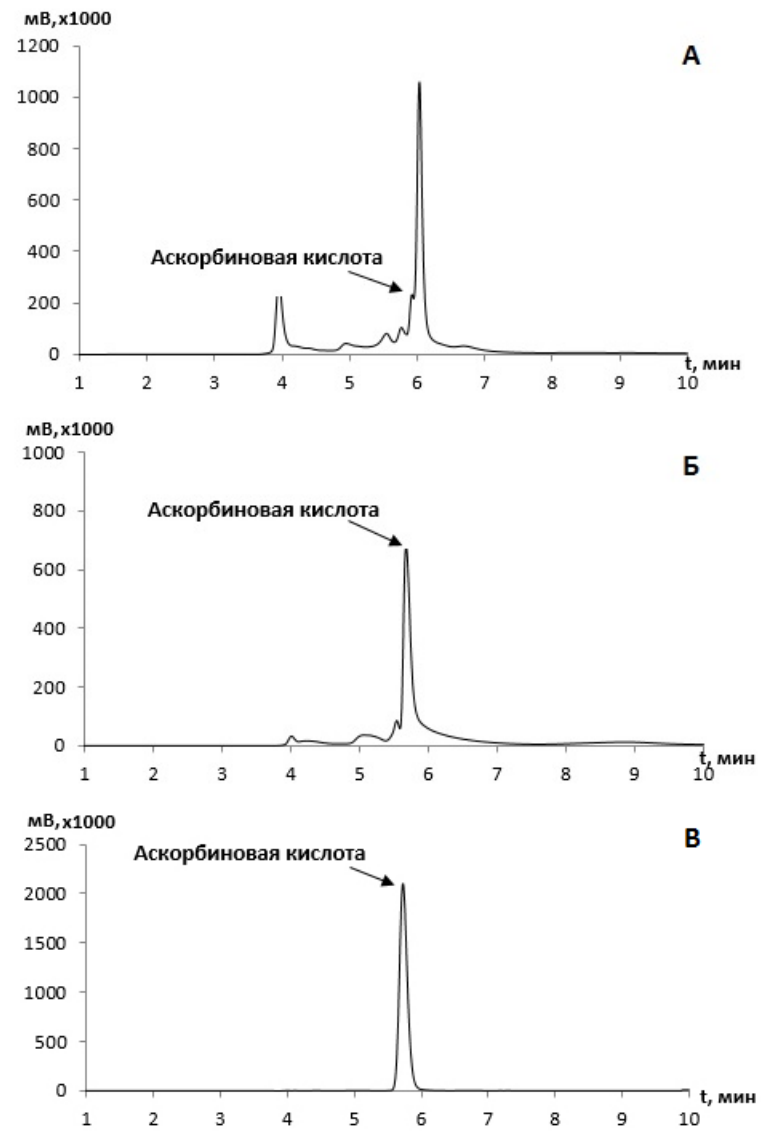

Puc. 2. Хроматограмма экстракта плодов шиповника (А), экстракта плодов боярышника (Б) и готового напитка на основе пектина с добавлением элеутерококка, боярышника и шиповника (разведение 1:2) (В)

Содержание аскорбиновой кислоты в экстрактах шиповника и боярышника было незначительным: $0,0013 \%(0,013$ мг/мл) или 0,065 мг на 5 мл в экстракте шиповника и $0,0103 \%(0,103$ мг/мл) или 0,515 мг на 5 мл в экстракте боярышника. Поэтому для достижения адекватного уровня потребления аскорбиновой кислоты, с учетом возможной частичной потерей ее в результате окисления в процессе хранения продукта, потребовалось ее дополнительное 
введение в количестве 100 мг (1,0\% по общей массе сухого концентрата напитка) (рис. 2 В).

По результатам экспериментов установлено, что содержание флавоноидов в экстракте плодов шиповника составляет $0,0406 \%$, в экстракте плодов боярышника $-0,0824 \%$, а в готовом продукте $-0,0612 \%$. Количественный показатель составил для экстракта шиповника 0,406 мг/мл, а для экстракта боярышника - 0,824 мг/мл. Соответственно, в 5-ти мл экстракта шиповника содержится 2,03 мг флавоноидов, а в 5-ти мл экстракта боярышника - 4,12 мг флавоноидов. Суммарное содержание флавоноидов составляет 6,15 мг или $20,5 \%$ от их суточного адекватного уровня потребления.

Основываясь на результатах проведенных исследований были установлены следующие значения содержания ингредиентов в расчете на указанное количество сухого концентрата напитка - 10 г: экстракт шиповника $-5,0$ мл; экстракт боярышника - 5,0 мл; стевиозид - 60,0 мг, экстракт бузины - 50,0 мкл; лимонная кислота $-40,0$ мг.

Рецептура сухого концентрата напитка представлен в таблице 1.

Таблииа 1

Рецептура композици сухого концентрата напитка (в расчете на 1 кг готового продукта)

\begin{tabular}{|l|c|c|}
\hline \multicolumn{1}{|c|}{ Наименование сырья } & Единица измерения & Количество \\
\hline Сахароза & г & 711 \\
\hline Гидролизованный пектин из филлоспадикса & $\Gamma$ & 200 \\
\hline Экстракт плодов шиповника жидкий & мл & 500 \\
\hline Экстракт плодов боярышника жидкий & мл & 500 \\
\hline Экстракт элеутерококка жидкий & мл & 56,2 \\
\hline Кислота аскорбиновая & $\Gamma$ & 10 \\
\hline Кислота лимонная & г & 4 \\
\hline Стевиозид & мл & 6 \\
\hline Экстракт бузины жидкий & & 5 \\
\hline
\end{tabular}

Для производства сухого концентрата напитка была разработана технологическая схема, представленная на рисунке 3.

Все сухие компоненты просеивали через сито с размером отверстий не более 0,5 мм. Затем компоненты в количествах, указанных в таблице 1 , отвешивали на весах с погрешностью не более $0,1 \%$.

Экстракты шиповника, боярышника и элеутерококка отмеряли с помощью мерного цилиндра в количествах, указанных в таблице 1, смешивали и упаривали под вакуумом (при остаточном давлении не более 0,02 МПа) до конечного объема смеси 100 мл, затем охлаждали и добавляли экстракт бузины.

В емкость для смешивания, объемом 10,0 л помещали сахарную пудру, аскорбиновую кислоту, лимонную кислоту и стевиозид, затем добавляли полученный ранее концентрат экстрактов шиповника, боярышника, элеутерококка и бузины и вымешивали полученную смесь до однородной массы (визуальный контроль). Затем при постоянном перемешивании к полученной смеси постепенно добавляли гидролизованный пектин из филлоспадикса. После добавления всего количества пектина смесь продолжали вымешивать до получения однородной массы. 


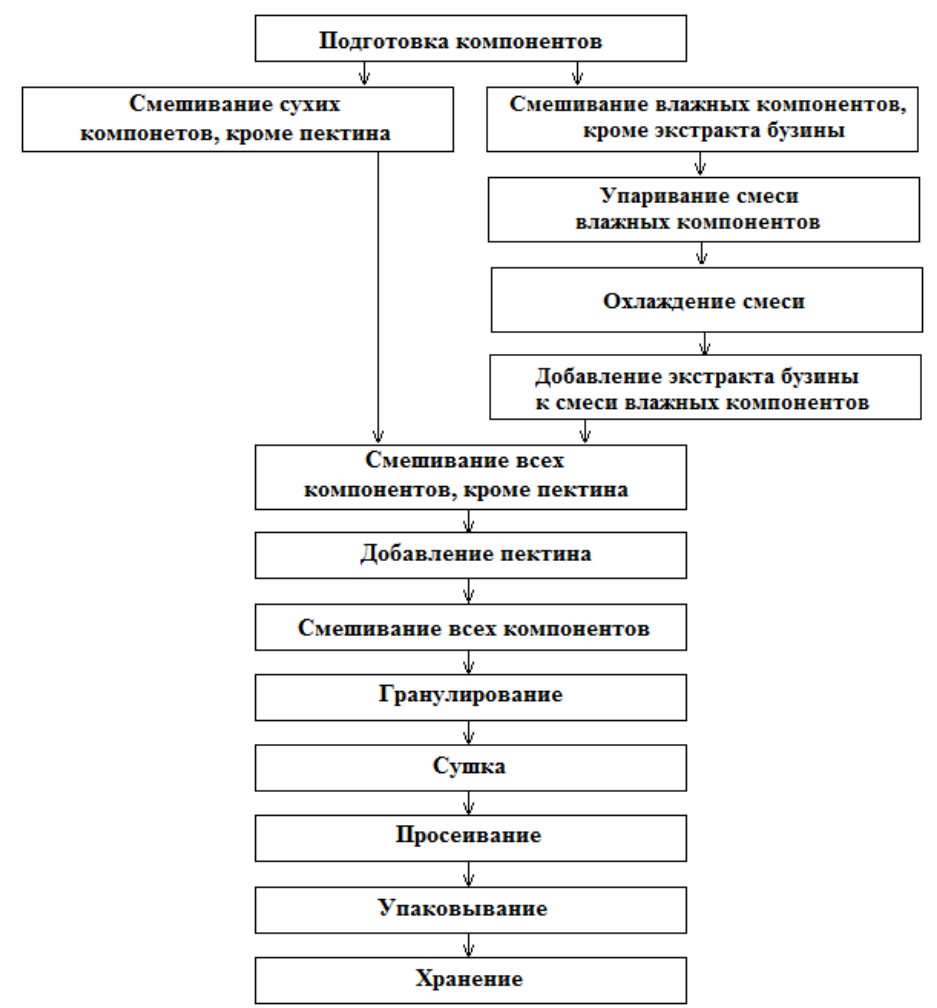

Puc. 3. Технологическая схема производства сухого концентрата напитка

Полученную влажную массу пропускали через гранулятор, в котором устанавливали решетку с отверстиями диаметром 3-4 мм.

Сушку гранулята осуществляли в сушилке при температуре не выше $80^{\circ} \mathrm{C}$ до остаточной влажности не более $8 \%$.

Сухой гранулят просеивали через сито с размером отверстий 2-3 мм и упаковывали в герметичную тару. Готовый продукт проверяли на содержание элеутерозидов, аскорбиновой кислоты и флавоноидов.

С момента окончания технологического процесса сухой концентрат напитка хранят в сухом темном месте при комнатной температуре. Сухой концентрат напитка упаковывают в потребительскую тару согласно ТР ТС 005/2011. Рекомендуется использовать герметичную тару для лучшего сохранения полезных веществ.

Органолептические показатели напитка на основе пектина с добавлением экстрактов элеутерококка, боярышника и шиповника оценивали с помощью профильного метода по ГОСТ 6687.5-86, ISO 11035:1994 [90, 106]. Изучали внешний вид, цвет, вкус, запах. Для этого суточную дозу сухого концентрата напитка (10 г) растворяли в 200 мл воды при комнатной температуре. Данные органолептических исследований функционального напитка на представлены в табл. 2 и на рис. 4. 
Органолептическая оценка приготовленного напитка на основе модифицированного пектина с добавлением экстрактов элеутерококка, боярышника и ииповника

\begin{tabular}{|c|c|c|}
\hline Показатель & $\begin{array}{c}\text { Значение показателя напитка на осно- } \\
\text { ве модифицированного пектина из } \\
\text { филлоспадикса с добавлением элеуте- } \\
\text { рококка, боярышника и шиповника }\end{array}$ & $\begin{array}{l}\text { Значение показателя } \\
\text { по ГОСТ 28188-2014 }\end{array}$ \\
\hline $\begin{array}{l}\text { Внешний вид и } \\
\text { консистенция }\end{array}$ & $\begin{array}{l}\text { непрозрачная жидкость, без осадка и } \\
\text { посторонних частиц }\end{array}$ & $\begin{array}{l}\text { непрозрачная жидкость. Допускается } \\
\text { наличие осадка и взвесей, обусловлен- } \\
\text { ных особенностями используемого } \\
\text { сырья, без включений, несвойственных } \\
\text { продукту }\end{array}$ \\
\hline Цвет & коричнево-розовый & \multirow{3}{*}{$\begin{array}{l}\text { свойственный добавленным компонен- } \\
\text { там согласно рецептуре }\end{array}$} \\
\hline Запах & $\begin{array}{l}\text { с ягодным ароматом, с выраженным } \\
\text { запахом шиповника }\end{array}$ & \\
\hline Вкус & $\begin{array}{l}\text { сладкий, свойственный добавленным } \\
\text { компонентам }\end{array}$ & \\
\hline
\end{tabular}

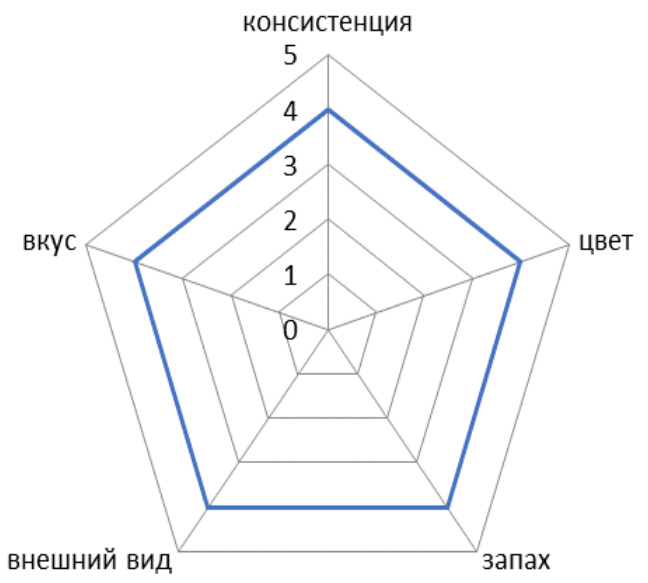

Puc. 4. Органолептическая оценка приготовленного напитка на основе пектина с добавлением экстрактов элеутерококка, боярышника и шиповника

Из табл. 2 и рис. 4 видно, что по органолептическим показателям напиток на основе пектина из филлоспадикса, обогащенный экстрактами элеутерококка, боярышника и шиповника соответствовал ГОСТ 28188-2014.

Напиток - непрозрачный, без осадка, коричневато-розоватого оттенка, с некоторым блеском, с ягодным ароматом, присущим шиповнику и в меру сладким вкусом, свойственным добавленным компонентам.

Профилограмма вкусового комплекса напитка на основе пектина из филлоспадикса с добавлением элеутерококка, боярышника и шиповника представлена на рис. 5. 


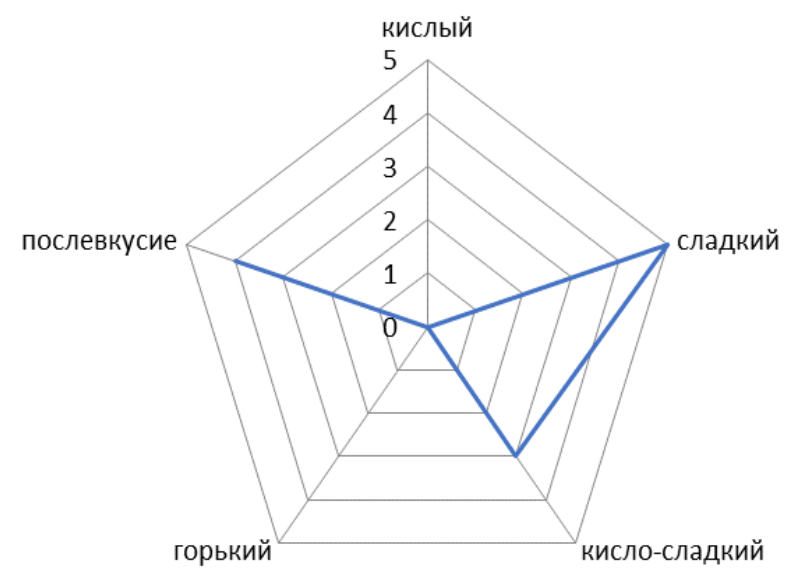

Puc. 5. Профилограмма вкусового комплекса напитка на основе пектина с добавлением элеутерококка, боярышника и шиповника

Вкус образца напитка распределен неравномерно, но при этом не имеет отрицательных для потребителя свойств. Можно отметить более выраженный сладкий вкус с приятным кисло-сладким послевкусием, обусловленным добавлением витамина $\mathrm{C}$, лимонной кислоты и экстрактов плодов шиповника и боярышника.

На рис. 6 отражена профилограмма внешнего вида напитка.

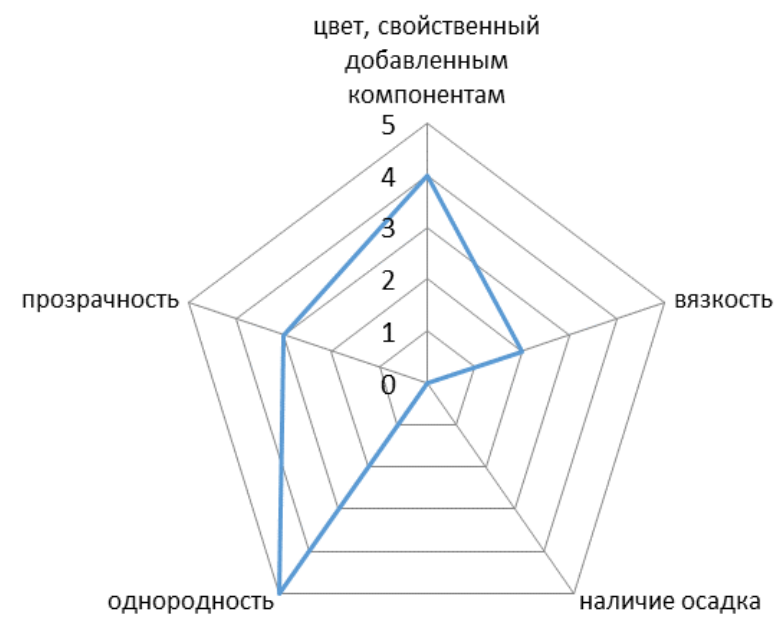

Puc. 6. Профилограмма внешнего вида напитка на основе пектина с добавлением элеутерококка, боярышника и шиповника

Внешний вид напитка также не имеет проявления отрицательных для потребителя свойств. Консистенция напитка непрозрачна, однородна, без осадка, не вязкая. Цвет соответствует добавленным компонентам. 
При исследовании физико-химических показателей определяли массовую долю сухих веществ, влажность и минеральные вещества сухого концентрата напитка, а также титруемую кислотность в готовом напитке в соответствие с действующей НД.

Массовая доля сухих веществ сухого концентрата напитка составила 94,7 $\pm 0,1$. Массовая доля минеральных веществ в сухом концентрате напитка составила 4,910 $\pm 0,001$ г и находится в пределах нормы.

Влажность контрольных образцов сухого концентрата напитка определялась в соответствии с ГОСТ Р 52610-2006 и составила 5,3 $\pm 0,1 \%$, что соответствует допустимым значениям.

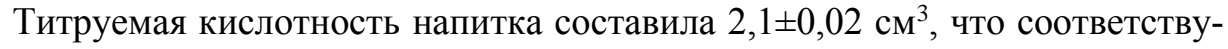
ют нормам ГОСТ 6687.4-86 и ТР ТС 021/2011 (при допустимых уровнях значений 1,0-15,0 см ${ }^{3}$ ). Кислотность напитка обуславливается самим пектином, лимонной и аскорбиновой кислотой, а также органическими кислотами, поступающими с экстрактами шиповника и боярышника. Кислоты придают напитку специфический вкус и тем самым способствуют его лучшему усвоению.

Определение безопасности контрольных образцов сухого концентрата напитка на основе пектина с добавлением экстрактов элеутерококка, шиповника и боярышника было проведено в соответствии с ТР ТС 021/2011. В ходе испытаний в сухом концентрате напитка определяли содержание тяжелых металлов и уровень микробиологической безопасности (КМАФАнМ, БГКП, патогенные микроорганизмы, дрожжи и плесени, E. coli).

Полученные результаты содержания тяжёлых металлов в сухом концентрате напитка представлены в табл. 3 и соответствуют НД.

Таблица 3

Содержание тяжёлых металлов в сухом концентрате напитка на основе модифицированного пектина из филлоспадикса с добавлением элеутерококка, ииповника и боярышника

\begin{tabular}{|l|c|c|l|}
\hline $\begin{array}{c}\text { Токсичные } \\
\text { элементы }\end{array}$ & $\begin{array}{c}\text { Величина допустимого } \\
\text { уровня по ТР ТС 021/2011, } \\
\text { мг/кг, не более }\end{array}$ & $\begin{array}{c}\text { Фактическое } \\
\text { значение, мг/кг }\end{array}$ & $\begin{array}{c}\text { НД на методы } \\
\text { испытаний }\end{array}$ \\
\hline Свинец & 5,0 & $0,38 \pm 0,13$ & ГОСТ Р 51301-99 \\
\hline Мышьяк & 3,0 & $0,094 \pm 0,038$ & ГОСТ 31628-2012 \\
\hline Кадмий & 1,0 & $0,120 \pm 0,038$ & ГОСТ Р 51301-99 \\
\hline Ртуть & 1,0 & $<0,005$ & МУ 5178-90 \\
\hline
\end{tabular}

Микробиологические показатели качества сухого концентрата напитка представлены в таблице 4 и соответствуют требованиям ТР ТС 021/2011.

Таблииа 4

Микробиологические показатели сухого концентрата напитка на основе модифицированного пектина из филлоспадикса с добавлением элеутерококка, ииповника и

\begin{tabular}{|c|c|c|c|}
\hline \multicolumn{4}{|c|}{ боярышника } \\
\hline Наименование показателя & $\begin{array}{c}\text { Величина допу- } \\
\text { стимого уровня } \\
\text { по ТР ТС 021/2011 }\end{array}$ & $\begin{array}{c}\text { Фактическое } \\
\text { значение }\end{array}$ & $\begin{array}{l}\text { НД на методы } \\
\text { испытаний }\end{array}$ \\
\hline $\begin{array}{l}\text { Патогенные, в том числе сальмо- } \\
\text { неллы, КОЕ } / \mathrm{cm}^{3} \text { в } 10 \text { г }\end{array}$ & не допускается & не обнаружено & ГОСТ 31659-2012 \\
\hline КМАФАнМ, КОЕ/Г & не более $5 \times 10^{4}$ & $2 \times 10^{2}$ & ГОСТ 10444.15-94 \\
\hline
\end{tabular}




\begin{tabular}{|l|c|c|c|}
\hline БГКП (колиформы) в 0,1 г & не допускается & не обнаружено & ГОСТ 31747-2012 П 5 \\
\hline E. coli в 1 г & не допускается & не обнаружено & ГОСТ 30726-2001 \\
\hline $\begin{array}{l}\text { Дрожжи и плесени (в сумме), } \\
\text { КОЕ/см }\end{array}$ & не более 100 & $<10$ & ГОСТ 10444.12-2013 \\
\hline
\end{tabular}

Из табл. 4 видно, что патогенные микроорганизмы, БГКП и E. coli обнаружены не были. Дрожжи и плесени в допустимых пределах. Разработанный напиток соответствует требованиям ТР ТС 021/2011 «О безопасности пищевой продукции».

\section{Заключение}

Разработана технология и рецептура композиции сухого концентрата напитка, содержащего комплекс биологически активных веществ: гидролизованный пектин из Phyllospadix iwatensis, элеутерозиды, флавоноиды, аскорбиновая кислота. Установлено соотношение функциональных ингредиентов в сухом концентрате напитка, определены дозы всех ингредиентов с учетом данных физико-химических исследований и норм суточного потребления. Исследован процесс гранулирования композиции пектина с добавлением экстрактов элеутерококка, шиповника и боярышника. Установлено, что полученный сухой концентрат напитка является функциональным по содержанию пектина, элеутерозидов, аскорбиновой кислоты и суммы флавоноидов. Содержание пектина, элеутерозидов и аскорбиновой кислоты в однократной дозировке напитка (10 г) составляет $100 \%$ от адекватного суточного уровня потребления. Содержание флавоноидов составляет 20,5 \% от адекватного суточного уровня потребления. Полученный напиток имеет приятный ягодный аромат, с выраженным запахом шиповника.

\section{Список источников / References}

1. Титлянов Э.А., Титлянова Т.В., Белоус О.С. Полезные свойства морских зеленных макроводорослей (Clorophyta) и морских трав (Magnoliophyta): структура, содержание, накопление использование. Известия ТИНРО, 2011, т. 166, сc. 283-296. [Titlyanov E.A., Titlyanova T.V., Belous O.S. Poleznye svoistva morskikh zelennykh makrovodoroslei (Clorophyta) i morskikh trav (Magnoliophyta): struktura, soderzhanie, nakoplenie ispol'zovanie [Useful properties of marine green macroalgae (Clorophyta) and sea grasses (Magnoliophyta): structure, content, accumulation use]. Izvestiya TINRO = Bulletin of PFORI, 2011, vol. 166, pp. 283-296.]

2. Валышев А.В. Антимикробная активность пектинов и их производных [Valyshev A.V. Antimikrobnaya aktivnost' pektinov i ikh proizvodnykh [Antimicrobial activity of pectins and their derivatives]. Available at: http://elmag.uran.ru:9673/magazine/Numbers/2013-3/Articles/ValyshevAV(2013-3).pdf.

3. Потороко И.Ю. и др. Антиоксидантные свойства функциональных пищевых ингредиентов, используемых при производстве хлебобулочных и молочных продуктов, их влияние на качество и сохраняемость продукции. Вестник ВГУИТ, 2017, т. 79, № 4, cc. 143-151. [Potoroko I.Yu. i dr. Antioksidantnye svoistva funktsional'nykh pishchevykh ingredientov, ispol'zuemykh pri proizvodstve khlebobulochnykh i molochnykh produktov, ikh vliyanie na kachestvo i sokhranyaemost' produktsii [Antioxidant properties of functional food ingredients used in the production of bakery and dairy prod- 
ucts, their impact on the quality and persistence of products]. Vestnik VGUIT $=$ Bulletin of VSUET, 2017, vol. 79, no. 4, pp. 143-151.]

4. Хобракова В.Б. Перспективы использования средств растительного происхождения для коррекции иммунодефицитов. Бюллетень ВСНЦ СО РАМН, 2010, № 3 (73), сс. 278-280. [Khobrakova V.B. Perspektivy ispol'zovaniya sredstv rastitel'nogo proiskhozhdeniya dlya korrektsii immunodefitsitov [The prospects of plant origin agents use for the immunodeficiencies correction] Vestnik of VSNC SO RAMN = Bulletin of SSC of RAMS, 2010, no. 3 (73), pp. 278-280.]

5. Шашель В.А. и др. Реабилитация в условиях бальнеолечебницы детей с эрозивноязвенными заболеваниями желудка и двенадцатиперстной кишки, проживающих на территориях с неблагоприятными экологическими условиями. Медицинский вестник Северного Кавказа, 2011, № 2, сc. 16-19. [Shashel' V.A. i dr. Reabilitatsiya v usloviyakh bal'neolechebnitsy detei s erozivno-yazvennymi zabolevaniyami zheludka i dvenadtsatiperstnoi kishki, prozhivayushchikh na territoriyakh $\mathrm{s}$ neblagopriyatnymi ekologicheskimi usloviyami [Rehabilitation in the conditions of balneological hospitals of children with erosive and ulcerative diseases of the stomach and duodenum, living in areas with adverse environmental conditions] Medical Bulletin of the North Caucasus, 2011, no. 2, pp. 16-19.]

6. Khozhaenko E.V. et al. Metal binding activity of pectin isolated from seagrass Zostera marina and its derivatives. Russian Journal of Marine Biology, 2015, vol. 41, no. 6, pp. 485-489. DOI 10.1134/S1063074015060073.

7. Коленченко Е.А., Хотимченко М.Ю., Хожаенко Е.В., Хотимченко Ю.С. Сорбция стронция пектинами, выделенными из морских трав Zostera marina и Phyllospadix iwatensis. Биология моря, 2012, т. 38, № 4, сc. 325-329. [Kolenchenko E.A., Khotimchenko M.Yu., Khozhaenko E.V., Khotimchenko Yu.S. Sorbtsiya strontsiya pektinami, vydelennymi iz morskikh trav Zostera marina i Phyllospadix iwatensis [Strontium sorption by pectins isolated from marine seagrasses Zostera marina and Phyllospadix iwatensis]. Russian Journal of Marine Biology, 2012, vol.38, pp.325-329.]

8. Khotimchenko Yu., Khozhaenko E., Kovalev V., Khotimchenko M. Cerium binding activity of pectins isolated from the seagrasses Zostera marina and Phyllospadix iwatensis. Marine drugs, 2012, vol. 10, no. 4, pp. 834-848. DOI: 10.3390/md10040834

9. Khozhaenko E., Kovalev V., Podkorytova E., Khotimchenko M. Removal of the metal ions from aqueous solutions by nanoscaled low molecular pectin isolated from seagrass Phyllospadix iwatensis. Science of the total environment, 2016, vol. 565, pp. 913-921. DOI: $10.1016 /$ j.scitotenv. 2016.01.108

10. Котик О.А. Перспективы использования растительных экстрактов с высокой антиоксидантной активностью в квасах брожения. Известия вузов. Пищевая технология, 2012, № 4, cc. 26-29 [Kotik O.A. Perspektivy ispol'zovaniya rastitel'nykh ekstraktov s vysokoi antioksidantnoi aktivnost'yu v kvasakh brozheniya [Prospects of plant extracts with high antioxidant activity use in the kvass fermentation.] Izvestiya vuzov $=$ News of universities. Food technology, 2012, no. 4, pp. 26-29.]

11. Гумеров Т.Ю., Решетник О.А. Роль природных адаптогенов при оценке качества напитков спортивного и функционального назначения. Вестник Казанского технологического университета, 2013, т. 16, № 18, сc. 219-223 [Gumerov T.Yu., Reshetnik O.A. Rol' prirodnykh adaptogenov pri otsenke kachestva napitkov sportivnogo i funktsional'nogo naznacheniya [The natural adaptogens role in assessing the quality of sports and functional beverages] Vestnik KTU = Bulletin of KTU, 2013, vol. 16, № 18, pp. 219-223.]

12. Подкорытов А.Г., Кадникова И.А., Подкорытова Е.А. Разработка технологии сухого концентрата напитка на основе пектина из морской травы Phyllospadix iwatensis c добавлением экстракта элеутерококка Eleutherococcus senticosus. Известия ДВФУ. Экономика и управление, 2018, №2, сc. 156-168 [Podkorytov A.G., Kadnikova I.A., Podkorytova E.A. Razrabotka tekhnologii sukhogo kontsentrata napitka na osnove pektina iz morskoi travy Phyllospadix iwatensis s dobavleniem ekstrakta eleuterokokka Eleuthe- 
rococcus senticosus] The technology development of a dry concentrate pectin-based beverage from seagrass Phyllospadix iwatensis with the addition of Eleutherococcus senticosus extract]. Izvestiya DVFU = News of FEFU. Economics and Management, 2018, no. 2, pp. 156-168.]

13. Единые санитарно-эпидемиологические и гигиенические требования к продукции (товарам), подлежащей санитарно-эпидемиологическому надзору (контролю) (утв. Решением Комиссии таможенного союза от 28 мая 2010 года N 299) (с изменениями на 10 мая 2018 года) (редакция, действующая с 1 июня 2019 года). [Edinye sanitarnoepidemiologicheskie $\mathrm{i}$ gigienicheskie trebovaniya $\mathrm{k}$ produktsii (tovaram), podlezhashchei sanitarno-epidemiologicheskomu nadzoru (kontrolyu) (utv. Resheniem Komissii tamozhennogo soyuza ot 28 maya 2010 goda N 299) (s izmeneniyami na 10 maya 2018 goda) (redaktsiya, deistvuyushchaya s 1 iyunya 2019 goda) [Unified sanitary-epidemiological and hygienic requirements for products (goods) subject to sanitary-epidemiological supervision (approved by the Decision of the Commission of the Customs Union No. 299 of May 28, 2010) (Amended on May 10, 2018) (revised from June 1, 2019)]. Available at: http://docs.cntd.ru/document/902249109\# (accessed 04.07.2018).

\section{Сведения об авторах / About authors}

Подкорытов Андрей Геннадьевич, аспирант Департамента пищевых наук и технологий, ШБМ, ФГАОУ ВО ДВФУ. E-mail: podkorytov_a_g@mail.ru

Кадникова Ирина Арнольдовна, доктор технических наук, профессор Департамента пищевых наук и технологий, ШБМ, ФГАОУ ВПО ДВФУ. E-mail: kadnirina@ mail.ru

Подкорытова Елена Алексеевна, кандидат биологических наук, научный сотрудник Лаборатории фармакологии ФГБУН «Национальный научный центр морской биологии им. А.В. Жирмунского» ДВО РАН. 690041, Россия, г. Владивосток, ул. Пальчевского, д. 17.

E-mail: eapodkorytova@mail.ru

Ковалев Валерий Владимирович, кандидат биологических наук, старший научный сотрудник Лаборатории фармакологии ФГБУН «Национальный научный центр морской биологии им. А.В. Жирмунского» ДВО РАН. 690041, Россия, г. Владивосток, ул. Пальчевского, д. 17.

E-mail: kovalev.ibm@gmail.com 